\title{
The Effect of Limbal Autograft Location at Primary Pterygium Excision on Anterior and Posterior Corneal Astigmatism: A Comparative Prospective Study
}

BURCU KAZANCI ( $\nabla$ drburcus@hotmail.com )

Ankara Ulucanlar Goz EAH: SBU Ulucanlar Goz Egitim Ve Arastirma Hastanesi https://orcid.org/00000002-0147-3841

Fatma Çorak Eroğlu

Ankara Ulucanlar Goz EAH: SBU Ulucanlar Goz Egitim Ve Arastirma Hastanesi Emine Şen

Ankara Ulucanlar Goz EAH: SBU Ulucanlar Goz Egitim Ve Arastirma Hastanesi

\section{Research Article}

Keywords: Astigmatism, Limbal autograft, Cornea, Pterygium

Posted Date: July 6th, 2021

DOI: https://doi.org/10.21203/rs.3.rs-657850/v1

License: (a) (i) This work is licensed under a Creative Commons Attribution 4.0 International License. Read Full License

Version of Record: A version of this preprint was published at International Ophthalmology on January 23rd, 2022. See the published version at https://doi.org/10.1007/s10792-022-02223-7. 


\section{Abstract}

Purpose: The aim of the study is to evaluate the effect of limbal autograft location on corneal astigmatism in inferior and superior conjunctival autografted pterygium surgery.

Methods: Patients were divided into 2 groups as diagnosed with primary pterygium and planned to receive surgical treatment. Pterygium surgery was performed 25 patients with superior and 25 patients with inferior limbal autograft who have similar epidemiologic features. Cornea anterior and posterior surface keratometry (K) 1, K2, Kmax, peripheric radius (Rper) (the mean radius of curvature of the 7.0-9.0 $\mathrm{mm}$ ring area), refractive astigmatism and axis values, were examined. Corneal irregularity indices were the index of surface variance (ISV), index of vertical asymmetry (IVA, mm), index of height asymmetry $(\mathrm{IHA}, \mu \mathrm{m})$, index of height decentration $(\mathrm{IHD}, \mu \mathrm{m})$. The data were compared pre and postoperative and the effect of graft location on results was evaluated.

Results: K1 which is from the values of the cornea front face has risen after surgery both of superior and inferior groups $(p=0.011)$. However, no postoperative significant difference was detected in terms of the change. Otherwise, both of groups $(p<0.001)$ have changed regarding astigmatism and Rper, but no postoperative significant difference was found in terms of the change. There were not any differences between groups regarding the changes of postoperative back face values. A significant decrease was detected on ISV, IVA, IHD values of the SLAG group $(p<0.001)$ and ILAG group $(p<0.001)$ in terms of all corneal anterior surface indices. However, there was no significant difference between the groups regarding the results of postoperative $(p>0.05)$.

Conclusion: The effects of pterygium surgery with limbal autograft were not significant on corneal astigmatism. However, we suggest that for the cases which need the protection of bulbar conjunctiva or when it can not be used, inferior bulbar conjunctiva preference can achieve successful results.

\section{Introduction}

Pterygium is the elastoid degeneration of the conjunctiva in which ultraviolet $B$ is blamed in its etiology that progresses from the bulbar area to the cornea in a triangular shape [1, 2]. This is supported by the high incidence of patients who work outside and more common in areas close to the Equator. In addition, heat, wind, and sand are thought to play a role in etiology $[2,3]$.

In pterygium, surgery is planned due to closure of the visual axis of the fibrovascular structure, decreased vision with the changes in topographic, refractive and wavefront analysis, recurrent inflammation, and cosmetic deformity. At the same time, pterygium excision is performed to obtain more accurate biometry values before cataract surgery [3-9]. Bare sclera excision, conjunctival transposition, mitomycin C or Beta radiation application added techniques were performed in pterygium treatment [1]. However, contemporarily the more secure than the other methods and accepted as 'golden standard' method is 'Conjunctival Autograft' [2-10]. 
The superior bulbar conjunctiva is generally preferable in terms of easier manipulation of the graft. However, it is crucial to protect the superior bulbar conjunctiva for the success of glaucoma surgery that is already done or planned to be done [11]. In addition it is not possible to take a graft from the superior bulbar conjunctiva in case of cicatrization. In such cases, instead of the superior bulbar conjunctiva, the inferior bulbar conjunctiva can be preferred as a graft location [11]. It was demonstrated that there was no difference regarding the recurrence in pterygium excision with autograft which was performed by taking graft from inferior or superior conjunctiva [2,11-13]. Many types of research show the effectiveness of pterygium surgery with autograft on the recovery of postoperative front and back corneal astigmatism [9, 14-16]. However, there is still no study about the effect of graft location choice between superior and inferior on post-surgery astigmatism.

To the best of our knowledge, this is the first study which aimed to evaluate comparatively the effect of pterygium surgery with autograft by taking graft from superior or inferior on astigmatism and cornea topographic data.

\section{Materials And Methods}

This prospective, comparative, observational study consisting of interventional case series was conducted between August 2020 and June 2021 at a tertiary ophthalmology hospital. The study was approved by the Institutional Ethics Committee and was performed in accordance with the principles of the Declaration of Helsinki. Informed consent was obtained from all participants.Study Population

A total of 50 eyes of 50 consecutive patients who were diagnosed as primary pterygium and underwent pterygium excision with conjunctival autograft by a single experienced surgeon (BK) were included in the study. Primary pterygium cases with a limbus of at least $1.5 \mathrm{~mm}$ were included in the study. The graft location of patients was decided randomly as 25 patients superior bulbar conjunctival graft (group 1), and 25 patients inferior bulbar conjunctival graft (group 2).

Patients who have a history of glaucoma, ocular surface surgery or trauma, limbal stem cell failure which cause pterygium in another location of the cornea, conjunctival scar or symblepharon, and double-headed pterygium were not included in this study.

\section{Assessment}

At the preoperative visit, all the patients underwent a complete ophthalmic examination, which included best-corrected distance visual acuity (BCVA), intraocular pressure (IOP), slit-lamp biomicroscopic examination and dilated fundus examination. In a biomicroscopic examination, the pterygium was graded with Tan's grading system [17], as grade 1 (atrophic) with episcleral vessels under the body of the pterygium not obscured and clearly distinguishable; grade 3 (fleshy) with episcleral vessels totally obscured, or grade 2 (intermediate) for all other pterygium not falling into grades 1 or 3 . Corneal topographic measurements of the patients in pre-operation and 6 months after the operation were performed by the same technician using Pentacam (Oculus, Inc., Germany). Indices which show corneal 
irregularity with cornea front and back face keratometry (K) 1, K2, Kmax, peripheric radius (Rper) (the mean radius of curvature of the $7.0-9.0 \mathrm{~mm}$ ring area), refractive astigmatism and axis values, were examined. These indices were an index of surface variance (ISV), index of vertical asymmetry (IVA, mm), index of height asymmetry (IHA, $\mu \mathrm{m})$, an index of height decentration (IHD, $\mu \mathrm{m})$. ISV is measured as the standard deviation of individual sagittal radii from mean curvature. IVA is the mean difference between superior and inferior corneal curvature. IHA is the mean difference between corneal elevation in the superior hemisphere and inferior hemisphere in the horizontal meridian. IHD measures vertical decentration of elevation data calculated using Fourier analysis. These measurements were evaluated by the blinded researcher who did not know which patient in the which group.

\section{Surgical Technique}

The patient was draped and prepared for operation under sterile conditions. The involved eye was anesthetized with topical ( $0.5 \%$ proparacaine hydrochloride, Alcaine, Alcon, Belgium) and subconjunctival (lidocaine hydrochloride $40 \mathrm{mg} / 2 \mathrm{ml}$, epinephrine $0.025 \mathrm{mg} / 2 \mathrm{ml}$, Jetokain, Adeka, Turkey) anesthetic. The pterygium tissue was removed with blunt and sharp dissection by removing the corneal epithelium $2 \mathrm{~mm}$ from the central pterygium cap, and so bare sclera was revealed. Autografts to the same extent as the scleral opening were randomly prepared from the superior or inferior bulbar conjunctiva of the same sideeye. The graft was sutured with an 8.0 polyglactin absorbable surgical suture (DemeTech, USA) to close the scleral opening. Conjunctival opening from the location that autograft was taken, was closed with 8.0 polyglactin absorbable surgical suture (DemeTech, USA). The operation was terminated with the injection of gentamicin $(1600 \mathrm{mg} / 2 \mathrm{ml}$, Genta ampul, iE Ulugay, İstanbul, Turkey) and dexamethasone (Dekort ampul, $8 \mathrm{mg} / \mathrm{ml}$, Deva, İstanbul, Turkey). After Deksametazon/moksifloksasin fix combination (Moxi-dexa damla, Abdi ibrahim, Turkey) 4 times a day for two weeks was used, it suggested for patients to use Loteprednol drops two times a day in the following two weeks (Dolte, Abdi ibrahim, Turkey) and Moksifloksasin 2x1 (Vigamox, Alcon, Geneva, Switzerland).

\section{Statistically Analysis}

Statistical analysis was performed using SPSS 25.0 software (IBM Corporation, Armonk, NY, USA). The compliance of the variables to the normal distribution was examined with using visual (histogram) and analytical methods (Kolmogrov-Smirnov test). Statistics of the participants of this study were expressed with mean, standard deviation, and median values for continuous data. Statistical differences between groups were analyzed and interpreted by paired t-test in quantitative cases, Mann Whitney U Test and Wilcoxon tests. The comparisons of the gender and pterygium grade were made by $\mathrm{X}^{2}$ test. It was considered statistically significant when the p-value is lower than 0.05 .

\section{Results}

50 eye of 50 patients were included in the study. Pterygium excision was performed using a superior bulbar conjunctival graft for 25 eyes, and an inferior bulbar conjunctival graft for 25 eyes. The patients were followed up at least 6 months in the postoperative period. The mean age of the patients was 53.56 
\pm 10.29 (median: 55 (range $30-70$ )) years in the group 1 and $52.52 \pm 10.42$ (median: 54, range: $37-69$ )) years in the group 2. $(p=0.78)$. There were 13 males (\%52) in the first group and 14 males $(\% 56)$ in the second group and no significant differences were detected between the two groups. According to preoperative pterygium staging, the 9 of the patients who graft was taken from superior were grade 2, the 16 of the patient were grade 3 pterygium; the 7 of the patients who graft was taken from inferior is grade 2 , and the rest 18 ones were grade 3 pterygium. There was no significant difference between groups in terms of pterygium staging $(p=0.36)$. Preoperative groups did not show any significant difference in terms of $K 1$ and $K 2(p=0.79, p=0.4)$.

As demonstrated in Table 1, K1, Rper and astigmatism values from the cornea front face pentacam data showed a statistically significant improvement after surgery than before surgery in both graft groups.

A significant difference was not observed between the two groups when inferiorly and superiorly graft is taken from patients were compared regarding the cornea front face $\mathrm{K} 1, \mathrm{~K} 2, \mathrm{Kmax}$, Rper, astigmatism values and axis differences ( $p>0.05$, for every value) (Table 2 ).

In Table 3, when the corneal posterior pentacam data were compared before and after surgery, a significant decrease in Rper value was observed only in the upper conjunctival graft $(p=0.046)$.

There was no significant difference in the two groups after operation regarding cornea back faces K1, K2, Kmax, Astigmatism changes. ( $p>0.05$, for every value) (Table 4).

ISV, IVA, and IHD data of the corneal surface indices were significantly declined in Group 1 and Group 2 in post-operation compare to pre-operation (Table 5).

When a comparison was made between two groups regarding the changes after operation in ISV, IVA, IHA and IHD of corneal surface indices, no significant differences were detected (Table 6) (Fig. 1).

\section{Conclusion}

There are researches in literature which demonstrate astigmatism caused by pterygium decreased after surgically pterygium excision $[15,19-21]$. It has shown that removal of pterygium surgically with limbal autograft treatment is more secure and effective among other methods regarding recurrence and cosmetic $[21,22]$. However, the preference of graft location is still controversial today. Hence we aimed to research the effect of taking graft from a different location on cornea topographic data and astigmatism data which are the data that reveals the effect of the operation on visual quality. As the first study of literature which we investigate the effect of pterygium surgery with superior and inferior bulbar autograft on corneal astigmatism, when we evaluate cornea anterior face, flattest (K1) meridians were statistically steeper after the operation in the cases of taking autograft from both superior and inferior, meanwhile no significant difference was detected in the steepest (K2) meridian. While there was no difference in Maximum $\mathrm{K}$ values for the superior conjunctival graft group, a decrease was detected for the inferior conjunctival graft. At the same time, Rper values showed a statistically significant decline in both groups. 
As the cap of the pterygium approaches the corneal apex, a meniscus formed by the tear film layer between the raised pterygium tissue and the cornea causes significant flattening. This situation improves after the pterygium surgery and results in improvement of astigmatism [4]. Our research as well supports that a significant decline performs in K1, astigmatism value and Rper value of the anterior face.

The first researches which have investigated the change of posterior and anterior face astigmatism with pentacam after pterygium surgery belonged to Kheirkhah et al $[23,24]$. In the research three different surgical techniques have been used which are bare sclera with mitomycin $\mathrm{C}$, amnion graft, and free conjunctival graft [1]. As a result of the study, only astigmatism and axis values have examined in 96 patients and it was reported that anterior astigmatism decreased significantly, and posterior astigmatism was decreased but it was not a statistically significant difference [24]. In our study, unlike the study of Kheirkhah et al., we evaluated not only astigmatism values but also K1, K2, Kmax, Rper, Axis and Astigmatism changes for anterior and posterior surfaces. While $\mathrm{K} 1$ values show a significant difference for the anterior face, there was not any significant change for $\mathrm{K} 2$ values. Astigmatism values have decreased for both groups. In addition, Rper slope has also decreased which we think it is related to the disappearing of the mechanical effect of the pterygium. Rper has shown a change only in the superior conjunctival graft group for posterior face values, but there was no statistically significant difference for other values even if changes have shown. In the study of Kheirkhah et al. ${ }^{24}$, even if a decrease from 0.35 $\mathrm{D}$ to $0.32 \mathrm{D}$ was observed, no statistically significant difference was found. In our study similar to the study of Kheirkah, even though a decrease in posterior astigmatism for 2 groups was observed, it wasn't statistically significant.

Levinger et al [9] have evaluated surgery-induced astigmatism (SIA) and they have found a significant difference. In our study different from the study of Levinger et al., although we have obtained the change in the posterior face less than a significant change in the anterior face after pterygium surgery, we think the graft location does not affect anterior and posterior face corneal astigmatism. Our study's one of the limiting factors was the low number of patients, but if there can be more patients in studies, they can enlighten this subject more.

In the research of Misra et al. [3], they only took superior graft and they solely evaluated ISV and IVA which is from the corneal front face regularity indices and astigmatism data evaluated with pentacam. As a result, they have detected a decline in all data. In our study too we have found a decline in ISV, IVA and astigmatism values after surgery of graft taking from both superior and inferior. In addition, in our research as different from Misra et al. [3], we have examined IHD and IHA. Moreover, we have detected that IHA was not changing in the superior graft group, but the IHD indice has a decline. In the inferior graft group, IHA and IHD values have declined. However, when the postoperative superior and inferior groups were compared with each other, no significant difference was demonstrated in terms of anterior surface indices. We assessed this situation as assimetry which occurs independently from graft location recovers after the successful pterygium surgery. 
In conclusion, we aimed to investigate whether astigmatism changes are a factor when deciding on the graft location in this study and as a result, we demonstrated that a successful pterygium surgery with limbal conjunctival autograft is sufficient for the management of astigmatism regardless of whether the graft is taken from the superior or the inferior. The preference of surgeons and the clinical case of the patient should be considered when deciding graft location.

\section{Acknowledgements}

\section{Declarations}

\section{Acknowledgements}

\section{Compliance with ethical standards}

The study is in accordance with the 1964 Helsinki Declaration and its later amendments or comparable ethical standards. Ankara Training and Education Hospital Health Ethics Committee of Clinical Research accepted the research protocol (project number:235).

\section{Declaration of conflicting interests}

The author(s) declared no potential conflicts of interest with respect to the research, authorship, and/or publication of this article.

\section{Funding}

The author(s) received no financial support for the research, authorship, and/or publication of this article.

\section{Informed consent}

Informed consent was obtained from all individual participants included in the study.

\section{Data availability statement}

The authors confirm that the dataasupporting the findings of this study are available within the article [and/or] its supplementary materials.

\section{References}

1. Hovanesian JA, Starr CE, Vroman DT et al (2017) ASCRS Cornea Clinical Committee. Surgical techniques and adjuvants for the management of primary and recurrent pterygia. $\mathrm{J}$ Cataract Refract Surg 43(3):405-419

2. Yeung SN, Lichtinger A, Kim P, Elbaz U, Ku JY, Amiran MD, Gorfinkle N, Wolff R, Slomovic AR (2013) Superior versus inferior conjunctival autografts combined with fibrin glue in the management of primary pterygia. Cornea 32(12):1582-1586. doi:10.1097/ICO.0b013e3182a9e712 
3. Misra S, Craig JP, McGhee CN, Patel DV (2014) A Prospective Study of Pterygium Excision and Conjunctival Autograft With Human Fibrin Tissue Adhesive: Effects on Vision, Refraction, and Corneal Topography. Asia Pac J Ophthalmol (Phila) 3(4):202-206.

doi:10.1097/AP0.0000000000000006

4. Oldenburg JB, Garbus J, McDonnell JM, McDonnell PJ (1990) Conjunctival pterygia. Mechanism of corneal topographic changes. Cornea 9:200-204

5. Stern GA, Lin A (1998) Effect of pterygium excision on induced corneal topographic abnormalities. Cornea 17:23-27

6. Tomidokoro A, Oshika T, Amano S, Eguchi K, Eguchi S (1999) Quantitative analysis of regular and irregular astigmatism induced by pterygium. Cornea Jul 18(4):412-415. doi:10.1097/00003226199907000-00004

7. Lin A, Stern GA (1998) Correlation between pterygium size and induced corneal astigmatism. Cornea 17:28-30

8. Gumus K, Erkilic K, Topaktas D, Colin J (2001) Effect of pterygia on refractive indices, corneal topography, and ocular aberrations. Cornea Jan 30(1):24-29. doi:10.1097/ICO.0b013e3181dc814e

9. Levinger E, Sorkin N, Sella S, Trivizki O, Lapira M, Keren S (2020) Posterior Corneal Surface Changes After Pterygium Excision Surgery. Cornea Jul 39(7):823-826. doi:10.1097/IC0.0000000000002325

10. Tan DTH, Chong EW (2017) Management of pterygium. In: Mannis MJ, Holland EJ (eds) Cornea; Fundamentals, Diagnosis, Management. China. Elsevier, pp 1560-1572

11. Li W, Lou Y, Wang B (2021) Recurrence rate with inferior conjunctival autograft transplantation compared with superior conjunctival autograft transplantation in pterygium surgery: a meta-analysis. BMC Ophthalmol 21(1):131. doi:10.1186/s12886-021-01889-4

12. Zloto O, Rosen N, Leshno A, Rosner M (2017) Very long term success of pterygium surgery with conjunctival graft. Cont Lens Anterior Eye Aug 40(4):267-269. doi:10.1016/j.clae.2017.05.004

13. Chen Q, Li Y, Xu F, Yan Y, Lu K, Cui L, Li M (2015) Comparison of Inferior and Superior Conjunctival Autograft for Primary Pterygium. Curr Eye Res 40(8):786-791. doi:10.3109/02713683.2014.961612

14. Altan-Yaycioglu R, Kucukerdonmez C, Karalezli A, Corak F, Akova YA (2013) Astigmatic changes following pterygium removal: comparison of 5 different methods. Indian J Ophthalmol Mar;61(3):104-108. doi:10.4103/0301-4738.109379

15. Garg P, Sahai A, Shamshad MA, Tyagi L, Singhal Y, Gupta S (2019) A comparative study of preoperative and postoperative changes in corneal astigmatism after pterygium excision by different techniques. Indian J Ophthalmol Jul;67(7):1036-1039. doi:10.4103/ijo.IJO_1921_18

16. Gumus K, Topaktas D, Göktaş A, Karakucuk S, Oner A, Mirza GE (2012) The change in ocular higherorder aberrations after pterygium excision with conjunctival autograft: a 1-year prospective clinical trial. Cornea Dec;31(12):1428-1431. doi:10.1097/IC0.0b013e3182431465

17. Tan DT, Chee SP, Dear KB, Lim AS (1997) Effect of pterygium morphology on pterygium recurrence in a controlled trial comparing conjunctival autografting with bare sclera excision. Arch Ophthalmol Oct;115(10):1235-1240. doi:10.1001/archopht.1997.01100160405001 
18. Doctor K, Vunnava KP, Shroff R, Kaweri L, Lalgudi VG, Gupta K, Kundu G (2020) Simplifying and understanding various topographic indices for keratoconus using Scheimpflug based topographers. Indian J Ophthalmol Dec;68(12):2732-2743. doi:10.4103/ijo.IJO_2111_20

19. Errais K, Bouden J, Mili-Boussen I et al (2018) Effect of pterygium surgery on corneal topography. Eur J Ophthalmol 18(2):177-181

20. Demirok A, Simşek S, Ozdemir M, Türkiye V (2005) Effect of pterygium surgery on corneal topography. Cornea 24(4):505-506. doi:10.1097/01.ico.0000166892.76661.41

21. Kam KW, Young AL (2019) Fifteen-year results of a randomized controlled trial comparing $0.02 \%$ mitomycin C, limbal conjunctival autograft, and combined mitomycin $\mathrm{C}$ with limbal conjunctival autograft in recurrent pterygium surgery. Graefes Arch Clin Exp Ophthalmol 257(12):2683-2690. doi:10.1007/s00417-019-04499-5

22. Kilic A, Gurler B (2006) The efficiency of limbal conjunctival autografting in pterygium surgery. Eur J Ophthalmol 16(3):365-370. doi:10.1177/112067210601600302

23. Kheirkhah A, Safi H, Nazari R, Kaghazkanani R, Hashemi H, Behrouz MJ (2012) Effects of pterygium surgery on front and back corneal surfaces and anterior segment parameters. Int Ophthalmol Jun;32(3):251-257. doi:10.1007/s10792-012-9560-2

24. Kheirkhah A, Safi H, Molaei S, Nazari R, Behrouz MJ, Raju VK (2012) Effects of pterygium surgery on front and back corneal astigmatism. Can J Ophthalmol Oct;47(5):423-428.

doi:10.1016/j.jcjo.2012.07.002

\section{Tables}

Table 1. Pre and postoperative changes of corneal front face K1, K2, Kmax, Rper and astigmatism values in superior and inferior graft location 


\begin{tabular}{|c|c|c|c|c|}
\hline \multicolumn{2}{|l|}{ ANTERIOR CORNEAL SURFACE } & $\begin{array}{l}\text { Preoperative } \\
\text { Mean } \pm \text { SD }\end{array}$ & $\begin{array}{l}\text { Postoperative } \\
\text { Mean } \pm \text { SD }\end{array}$ & $\mathrm{p}^{\#, *}$ \\
\hline \multirow[t]{5}{*}{ SUPERIOR CONJONCTIVAL GRAFT } & $\mathrm{K} 1$ & $41.9 \pm 3.41$ & $43.02 \pm 1.69$ & $0.011^{\#}$ \\
\hline & K2 & $42.84 \pm 8.06$ & $44.14 \pm 1.3$ & $0.917^{\#}$ \\
\hline & $\mathrm{Kmax}^{*}$ & $44.92 \pm 2.08$ & $44.83 \pm 2.03$ & 0.771 * \\
\hline & Astigmatism & $2.51 \pm 3.56$ & $1.04 \pm 0.83$ & $0.005 \#$ \\
\hline & Rper* & $8.14 \pm 0.36$ & $7.97 \pm 0.26$ & $<0.001$ * \\
\hline \multirow[t]{5}{*}{ INFERIOR CONJONCTIVAL GRAFT } & $\mathrm{K} 1^{*}$ & $40.28 \pm 4.01$ & $43.47 \pm 1.68$ & $<0.001 *$ \\
\hline & $\mathrm{K} 2^{*}$ & $44.66 \pm 1.63$ & $44.41 \pm 1.98$ & 0.078 * \\
\hline & Kmax & $46.34 \pm 2.22$ & $45.74 \pm 2.94$ & $0.035^{\#}$ \\
\hline & Astigmatism & $4.36 \pm 3.92$ & $0.87 \pm 0.82$ & $<0.001 \#$ \\
\hline & Rper & $8.28 \pm 0.61$ & $7.95 \pm 0.26$ & $<0.001 \#$ \\
\hline \multicolumn{5}{|c|}{$\begin{array}{l}\text { K1; Flat keratometry, K2; steep keratometry; Kmax; Maximum keratometry; SD.; Standard deviation; } \\
\text { Rper; Periferik Radius (8-10 mm), : Paired sample t test, \#:Wilcoxon test, Significant p values are } \\
\text { written in bold. }\end{array}$} \\
\hline
\end{tabular}

Table 2. The comparison of corneal anterior surface K1, K2, Kmax, Rper and Astigmatism changes after the operation in the ones which graft was taken from superior and inferior. 


\begin{tabular}{|c|c|c|c|}
\hline & $\begin{array}{l}\text { SUPERIOR CONJONCTIVAL } \\
\text { GRAFT }\end{array}$ & $\begin{array}{l}\text { INFERIOR CONJONCTIVAL } \\
\text { GRAFT }\end{array}$ & $p^{\beta, \&}$ \\
\hline & Mean \pm SD & Mean \pm SD & \\
\hline K1 & $43,02 \pm 1,69$ & $43,47 \pm 1,68$ & $\begin{array}{l}0,356 \\
\&\end{array}$ \\
\hline K2 & $44,14 \pm 1,3$ & $44,41 \pm 1,98$ & $\begin{array}{l}0,574 \\
\&\end{array}$ \\
\hline KMAX & $44,83 \pm 2,03$ & $45,74 \pm 2,94$ & $\begin{array}{l}0,331 \\
\beta\end{array}$ \\
\hline Astigmatism & $1,04 \pm 0,83$ & $0,87 \pm 0,82$ & $\begin{array}{l}0,209 \\
\beta\end{array}$ \\
\hline Rper & $7,97 \pm 0,26$ & $7,95 \pm 0,26$ & $\begin{array}{l}0,779 \\
\&\end{array}$ \\
\hline $\begin{array}{l}\text { Ax differences } \\
\text { anterior }\end{array}$ & $16,97 \pm 16,99$ & $15,49 \pm 18,68$ & $\begin{array}{l}0,749 \\
\beta\end{array}$ \\
\hline $\begin{array}{l}\text { K1; Flat keraton } \\
\text { Rper; Periferik R } \\
\text { values are writt }\end{array}$ & $\begin{array}{l}\text { steep keratometry; Kmax; M } \\
-10 \mathrm{~mm}), \text { : Independent sa }\end{array}$ & $\begin{array}{l}\text { keratometry; SD.; Standard } \\
\text { test, } \beta \text { : Mann Whitney U tes }\end{array}$ & $\begin{array}{l}\text { ion; } \\
\text { ficant p }\end{array}$ \\
\hline
\end{tabular}

Table 3. Pre and postoperative changes of corneal posterior face K1, K2, Kmax, Rper and Astigmatism values in both graft locations. 


\begin{tabular}{|c|c|c|c|c|}
\hline \multicolumn{2}{|l|}{ POSTERIOR CORNEAL SURFACE } & PREOPERATIVE & POSTOPERATIVE & \multirow{2}{*}{$\mathrm{p}^{*} \#$} \\
\hline & & Mean \pm SD & Mean \pm SD & \\
\hline \multirow{5}{*}{$\begin{array}{l}\text { SUPERIOR CONJONCTIVAL } \\
\text { GRAFT }\end{array}$} & K1 & $-6.27 \pm 0.269$ & $-6.22 \pm 0.305$ & 0.141 * \\
\hline & $\mathrm{K} 2$ & $-6.54 \pm 0.3$ & $-6.59 \pm 0.462$ & 0.434 * \\
\hline & Kmax & $-6.39 \pm 0.255$ & $-6.4 \pm 0.301$ & 0.597 * \\
\hline & Astigmatism & $0.37 \pm 0.46$ & $0.27 \pm 0.234$ & $0.135 \#$ \\
\hline & Rper & $6.72 \pm 0.32$ & $6.6 \pm 0.292$ & 0.046 * \\
\hline \multirow[t]{5}{*}{ INFERIOR CONJONCTIVAL GRAFT } & $\mathrm{K} 1$ & $-5.42 \pm 3.751$ & $-6.15 \pm 0.31$ & 0.605 \# \\
\hline & $\mathrm{K} 2$ & $-6.23 \pm 1.702$ & $-6.58 \pm 0.454$ & 0.924 \# \\
\hline & Kmax & $-5.46 \pm 3.15$ & $-6.35 \pm 0.328$ & $0.680^{\#}$ \\
\hline & Astigmatism & $0.82 \pm 2.105$ & $0.42 \pm 0.408$ & 0.266 \# \\
\hline & Rper & $7.87 \pm 5.655$ & $6.7 \pm 0.311$ & $0.095^{\#}$ \\
\hline \multicolumn{5}{|c|}{$\begin{array}{l}\text { K1; Flat keratometry, K2; steep keratometry, Kmax; Maximum keratometry, SD.; Standard deviation, } \\
\text { Rper; Periferik Radius (8-10 mm), *: Paired sample t test, \#. Wilcoxon test. Significant p values are } \\
\text { written in bold. }\end{array}$} \\
\hline
\end{tabular}

Table 4. The comparison of corneal posterior surface K1, K2, Kmax, Rper and Astigmatism changes after the operation in the ones which gradt was taken superior and inferior. 


\begin{tabular}{|c|c|c|c|}
\hline $\begin{array}{l}\text { POSTERIOR CORNEAL } \\
\text { SURFACE }\end{array}$ & $\begin{array}{l}\text { SUPERIOR CONJONCTIVAL } \\
\text { GRAFT }\end{array}$ & $\begin{array}{l}\text { INFERIOR CONJONCTIVAL } \\
\text { GRAFT }\end{array}$ & $\begin{array}{l}p^{\beta} \\
\&\end{array}$ \\
\hline SURFACE & Mean \pm SD & Mean \pm SD & \\
\hline K1 & $-6,22 \pm 0,31$ & $-6,15 \pm 0,31$ & $\begin{array}{l}0,37 \\
\&\end{array}$ \\
\hline K2 & $-6,59 \pm 0,46$ & $-6,58 \pm 0,454$ & $\begin{array}{l}0,93 \\
\&\end{array}$ \\
\hline Kmax & $-6,4 \pm 0,30$ & $-6,35 \pm 0,33$ & $\begin{array}{l}0,56 \\
\&\end{array}$ \\
\hline Astigmatism & $0,37 \pm 0,46$ & $0,42 \pm 0,41$ & $\begin{array}{l}0,66 \\
\beta\end{array}$ \\
\hline Rper & $6,6 \pm 0,29$ & $6,7 \pm 0,31$ & $\begin{array}{l}0,25 \\
\&\end{array}$ \\
\hline Axial differences & $30,84 \pm 33,87$ & $37,346 \pm 36,65$ & $\begin{array}{l}0,35 \\
\beta\end{array}$ \\
\hline
\end{tabular}

K1; Flat keratometry, K2; steep keratometry; Kmax; Maximum keratometry; SD.; Standard deviation; Rper; Periferik Radius $(8-10 \mathrm{~mm})$, \&: Independent samples t test, ${ }^{\beta}$ : Mann Whitney U test.

Table 5. The comparison of cornea face indices pre and post operatively in the ones which graft was taken from superior and inferior. 


\begin{tabular}{|c|c|c|c|c|}
\hline & & PREOPERATIVE & POSTOPERATIVE & \multirow[t]{2}{*}{$p^{\#}$} \\
\hline & & Mean \pm SD & Mean \pm SD & \\
\hline \multirow[t]{4}{*}{ SUPERIOR CONJONCTIVAL GRAFT } & ISV & $58,84 \pm 44,12$ & $23,52 \pm 12,11$ & $<0,001 \#$ \\
\hline & IVA & $0,426 \pm 0,35$ & $0,178 \pm 0,09$ & $<0,001 \#$ \\
\hline & IHA & $8,544 \pm 8,62$ & $7,564 \pm 7,32$ & $0,15^{\#}$ \\
\hline & IHD & $0,04 \pm 0,02$ & $0,026 \pm 0,02$ & $0,02 \#$ \\
\hline \multirow[t]{4}{*}{ INFERIOR CONJONCTIVAL GRAFT } & ISV & $76,64 \pm 82,36$ & $20,16 \pm 5,757$ & $<0,001^{\#}$ \\
\hline & IVA & $0,57 \pm 0,69$ & $0,203 \pm 0,16$ & $0,001^{\#}$ \\
\hline & IHA & $10,98 \pm 8,38$ & $6,08 \pm 4,62$ & 0,01 \# \\
\hline & IHD & $0,05 \pm 0,03$ & $0,04 \pm 0,03$ & $0,07^{\#}$ \\
\hline
\end{tabular}

Table 6. The pre and post operatively comparison of the ones which graft was taken from superior and inferior 


\begin{tabular}{|c|c|c|c|c|}
\hline & & $\begin{array}{l}\text { SUPERIOR CONJONCTIVAL } \\
\text { GRAFT }\end{array}$ & $\begin{array}{l}\text { INFERIOR CONJONCTIVAL } \\
\text { GRAFT }\end{array}$ & \multirow[t]{2}{*}{$p^{\beta}$} \\
\hline & & Mean \pm SD & Mean \pm SD & \\
\hline \multirow[t]{4}{*}{ Preoperative } & ISV & $58,84 \pm 44,12$ & $76,64 \pm 82,36$ & $\begin{array}{l}0,53 \\
\beta\end{array}$ \\
\hline & IVA & $0,43 \pm 0,35$ & $0,57 \pm 0,69$ & $\begin{array}{l}0,63 \\
\beta\end{array}$ \\
\hline & $\mathrm{IHA}$ & $8,54 \pm 8,62$ & $10,98 \pm 8,38$ & $\begin{array}{l}0,19 \\
\beta\end{array}$ \\
\hline & IHD & $0,04 \pm 0,02$ & $0,05 \pm 0,03$ & $\begin{array}{l}0,21 \\
\beta\end{array}$ \\
\hline \multirow[t]{4}{*}{ Postoperative } & ISV & $23,52 \pm 12,11$ & $20,16 \pm 5,76$ & $\begin{array}{l}0,89 \\
\beta\end{array}$ \\
\hline & IVA & $0,18 \pm 0,09$ & $0,20 \pm 0,157$ & $\begin{array}{l}0,69 \\
\beta\end{array}$ \\
\hline & $\mathrm{IHA}$ & $7,56 \pm 7,32$ & $6,08 \pm 4,62$ & $\begin{array}{l}0,98 \\
\beta\end{array}$ \\
\hline & IHD & $0,03 \pm 0,02$ & $0,04 \pm 0,03$ & $\begin{array}{l}0,15 \\
\beta\end{array}$ \\
\hline
\end{tabular}

\section{Figures}




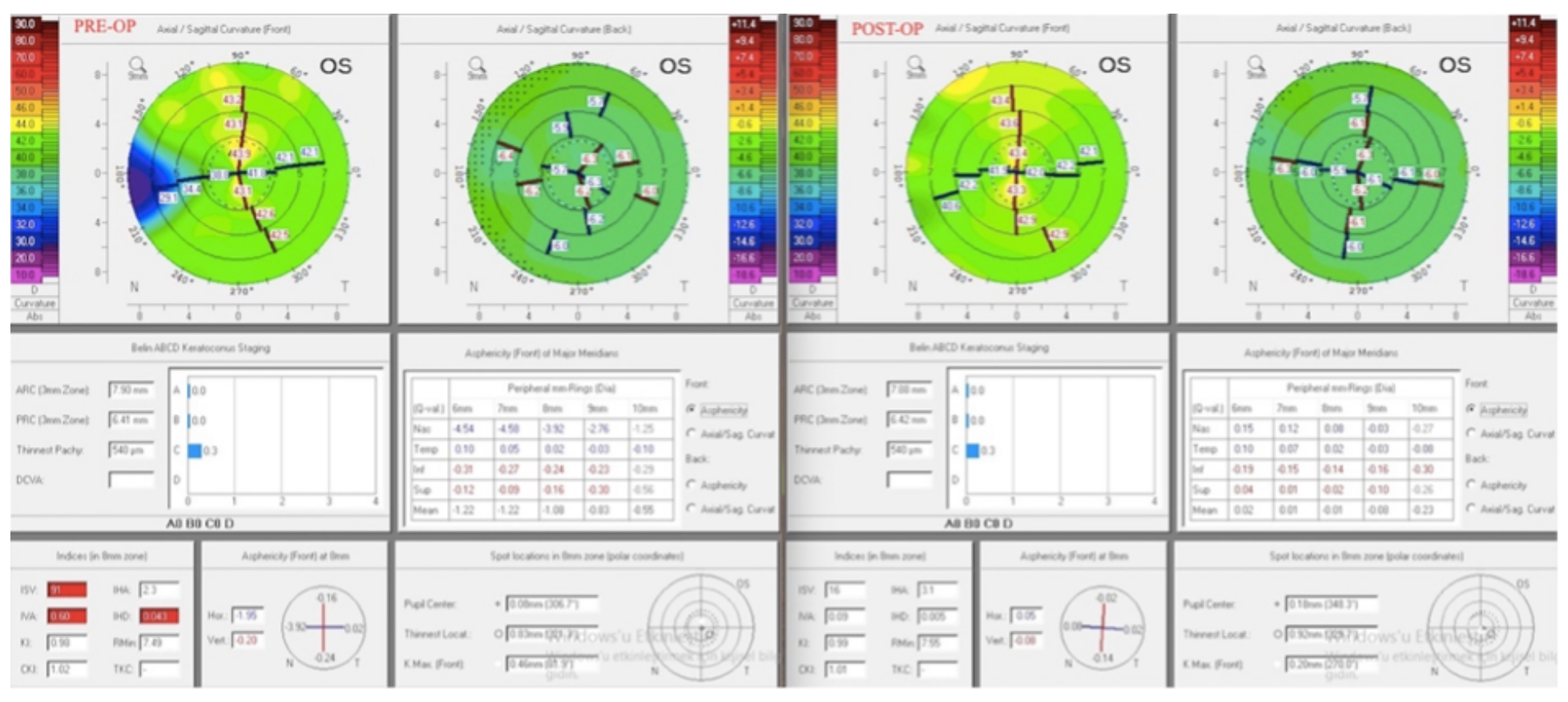

Figure 1

The change of pentacam index and topography in preoperative and postoperative 6th month. 